\title{
Overview Of Village Fund Allocation By Number Of Villages
}

\author{
Heru Kreshna Reza ${ }^{1 *}$, Kurniati Karim², Melly Susanti ${ }^{3}$ \\ ${ }^{1}$ Department of Accounting, Faculty of Economics and Business, Esa Unggul University, Indonesia \\ ${ }^{2}$ Department of Management, Faculty of Economics, STIE Sakti Alam Sungai Full Jambi,Indonesia \\ ${ }^{3}$ Department of Accounting, Faculty of Economics, Muhammadiyah Bengkulu University, Indonesia \\ ${ }^{*}$ Corresponding author : \\ Email: heru.kreshna@esaunggul.ac.id
}

\begin{abstract}
.
The existence of regional autonomy can increase regional income, villages can be more independent in managing village finances. This type of quantitative descriptive research will answer how big is the relationship between the Village Fund Allocation (ADD) given to each district and the number of villages. The populace in this review is the breakdown of town assets by area/city for monetary year 2020. Furthermore the example utilized in this review is subtleties of town assets by area/city for financial year 2020 in Bengkulu Province, which are 9 areas. The outcomes observed that the assignment of town subsidizes given to every area was as per the Regulation of the Minister of Finance of the Republic of Indonesia No. 193/Pmk.07/2018, however the aftereffects of the connection test showed that the connection between the allotment of town assets to the 9 locale and the quantity of towns shows the relationship that Average is equivalent to 0.411 .
\end{abstract}

Keywords: Village Fund, Basic Allocation, Performance Allocation, Affirmation Allocation

\section{INTRODUCTION}

The Execution of financial decentralization requires the presence of a focal government fit for managing and authorization. Financial decentralization expects to (1) increment the proficiency of the distribution of public assets and nearby government exercises, (2) satisfy local yearnings, work on the monetary construction, and activate territorial and public incomes, (3) increment responsibility, straightforwardness, and public interest in direction. at the local level, (4) working on the monetary harmony among areas and guaranteeing quality public administrations in every district, (5) creating social welfare for the community. Fiscal decentralization is a process of distributing the budget from higher levels of government to lower levels of government to support government functions in public services [6]. The basic principle that must be considered is money follows functions, which means that the delegation of government authority is followed by the delegation of funding as a consequence of the financing needed to carry out the said authority. To realize an effective and efficient government system, the Government has decentralized some of its powers and responsibilities to local governments. As the most minimal independent area in the Indonesian government framework, towns have impediments as far as financing all administration undertakings. The hindering variables in overseeing town assets in Lubuk Alung District are HR, delays in revealing, changes to the Village Budget, the web and local area understanding, (Ramly et al., 2018). The existence of autonomy or authority allows the village community to regulate themselves and manage their interests according to local conditions and socio-cultural conditions. The physical development budget is also directed and focused on improving the economy of rural communities by involving them in projects and other social activities in the village and by involving them to care about the development of their village [4].

Village autonomy allows the village government to have flexibility in the use of village funds. The arrangement and conveyance of Indications of the Need for Village Funds is directed by the Regulation of the Minister of Finance with respect to the techniques for arranging, investigating, and deciding allotments and is ready by considering 1) Percentage of Village Funds Determined in the Provisions of Legislation, 2) Execution of Implementation of Village Funds, c) Ability State accounts. The subtleties of the Village Fund for each area/city are directed dependent on passage (1) that the financial plan is assigned equitably and genuinely 
dependent on the fundamental allotment, insistence designation and recipe portion (Minister of Finance Regulation Number 193/PMK.07/2018). Town Financial Management in Indonesia has been controlled in a Ministerial Regulation Domestic Affairs Number 20 of 2018 that exercises incorporate preparation, budgeting, administration, reporting, accountability and supervision of village finances. Town Fund Management incorporates planning, allotment, and dissemination, as expressed in the Minister of Finance Regulation Number 193/PMK.07/2018. The portion of town subsidizes alludes to the fundamental assignment, attestation designation, execution allotment and equation distribution. Essential Allocation is the base allotment of Village Funds that will be gotten by every Village similarly, how much which is determined dependent on a specific level of the Village Fund spending plan isolated by the quantity of towns broadly.

The Basic Allocation is determined at $72 \%(72 \%)$ of the Village Fund spending plan partitioned similarly among every Village. Insistence Allocation is a portion determined by considering the situation with immature towns and exceptionally immature towns, which have countless needy individuals. Confirmation Allocation is determined at 3\% (three percent) of the Village Fund financial plan isolated relatively to burdened towns and extremely immature towns that have countless needy individuals. Equation Allocation is a designation determined by considering the quantity of town occupants, town destitution rate, space of the town, and the geological trouble level of each region/city Village. The Formula Allocation is determined at 25\% (25\%) of the Village Fund spending plan partitioned dependent on the quantity of Village inhabitants, the quantity of helpless Village occupants, the space of the Village, and the degree of geological trouble of the Village.The Management of village funds in improving the economy of rural communities has a fairly good weight and value as well as a score in the internal environment[8]. The use of village funds has an effect on community empowerment [11].

Moves to Regions and Village Funds (TKDD) are essential for State Expenditures designated in the State Revenue and Expenditure Budget to Regions and Villages to finance the execution of undertakings that have been submitted to Regions and Villages [14]. Village budget allocation policies and village fund allocations are the second source of village financial revenues [10]. Village funds provide loans to customers of informal financial institutions[7]. Susanti et al. in the International Conference they said that the APBDes management in Pematang Riding village had a surplus of Rp. 6.000.394, - meaning that the allocation of village funds cannot be accounted for, APBD funds have not been fully realized[13]. Fadli et al., found obstacles in villages in the Aceh region, namely that some of the work could not be realized by the residents, causing silpa for the following year [3]. Allocation of village funds (significantly negative) and village expenditures (significant and positive) on poverty levels through economic growth in Mahakam Ulu Regency[1]. Increasing the performance of village development management will encourage the implementation of village fund policies [2].

Village performance assessment for Performance Allocation in the allocation of Village Funds in 2020 and 2021 is still being carried out by the Central Government, Completing policies in the allocation of Village Funds to Villages, one of which is by providing Performance Allocations (AK) to villages that have the best performance assessment results. It is intended that villages can compete in a healthy manner in improving their performance [9]. In practice, the village government is obliged to manage village finances in a transparent, accountable, and participatory manner [5]. The town government actually thinks that it is hard to set up an Accountability Report for the Realization of the Implementation of the APBDes so the public authority gives help and direction[12]. Transparent means being managed openly, accountable means being legally accountable, and participatory means involving the community in the process. So far, the management of village funds has been transparent, accountable and legally accountable. However, with the allocation of village funds, it has not been able to measure how much the poverty rate has reduced in an area. This review plans to audit the Distribution of Village Funds Based on the Regulation of the Minister of Finance of the Republic of Indonesia No. 193/Pmk.07/2018, and to decide the connection between the allotment of town assets to the quantity of towns in every locale. Where the village fund allocation indicators used are basic allocations, formula allocations and performance allocations. The poverty rate used in 2021 . 


\section{METHODS}

\section{Types of Research}

The sort of exploration utilized in this examination is clear exploration, a review that plans to portray the consequences of the audit, in particular the assignment of town assets in the fundamental allotment, attestation distribution, execution designation and recipe portion. This portion is given to districts dependent on the Regulation of the Minister of Finance of the Republic of Indonesia No. 193/Pmk.07/2018. By using scientific methods to answer actual problems, such as the suitability and fairness of the allocation that has been given to the number of villages in each village through the calculation of statistical figures. This review utilizes a quantitative methodology, in particular examination that underscores investigation on mathematical information (numbers) which are handled by measurable strategies. With the quantitative strategy, the connection between the Allocation of Village Funds in every Regency will be acquired with the Number of Villages in the Regency of Bengkulu Province.

\section{Methods of data}

\section{Descriptive Analysis}

Descriptive analysis is used to describe and describe the research variables according to field conditions. In describing the data, descriptive statistics are used in the form of the average value, frequency, percentage and standard deviation.

\section{Quantitative Analysis Quantitative}

Investigation is utilized to survey the Amount of Village Fund Distribution Based on the Regulation of the Minister of Finance of the Republic of Indonesia No. 193/Pmk.07/2018, which incorporates Basic Allocations, Performance Allocations, Formulation Allocations, in light of the quantity of towns in every city/locale in Bengkulu.

\section{Population and Sample}

The populace in this review is the breakdown of town assets by region/city for the 2020 monetary year. In the mean time, the examples taken in this review are the subtleties of town assets by area/city for the 2020 monetary year in Bengkulu Province, which are 9 regions.

\section{RESULT AND DISCUSSION}

\section{Overview of Village Fund Allocation The}

Assignment of town reserves dependent on the quantity of towns in each locale in Bengkulu Province seen from the quantity of essential allotments, execution distributions and recipe designations should be visible in the accompanying table;

Table 1. Details of the Village Fund By Regency / City FY 2020

\begin{tabular}{|c|l|c|c|c|c|c|}
\hline No. & \multicolumn{1}{|c|}{$\begin{array}{c}\text { Bengkulu } \\
\text { province }\end{array}$} & $\begin{array}{c}\text { Total } \\
\text { Villages }\end{array}$ & $\begin{array}{c}\text { Allocation } \\
\text { Affirmations }\end{array}$ & $\begin{array}{c}\text { Allocation } \\
\text { Basic }\end{array}$ & $\begin{array}{c}\text { Allocation } \\
\text { Performance }\end{array}$ & $\begin{array}{c}\text { Allocation } \\
\text { Formula }\end{array}$ \\
\hline 1 & South Bengkulu & 142 & - & 94.118 .452 & 2.017 .344 & 16.373 .993 \\
\hline 2 & Rejang Lebong & 122 & - & 142.503 .290 & 3.170 .112 & 27.577 .562 \\
\hline 3 & Bengkulu Utara & 215 & 4.359 .217 & 80.862 .332 & 1.729 .152 & 27.566 .889 \\
\hline 4 & Kaur & 192 & - & 127.258 .752 & 2.737 .824 & 19.103 .335 \\
\hline 5 & Seluma & 182 & 181.634 & 120.630 .692 & 2.593 .728 & 19.646 .053 \\
\hline 6 & Mukomuko & 148 & - & 98.095 .288 & 2.161 .440 & 24.219 .244 \\
\hline 7 & Lebong & 93 & - & 61.640 .958 & 1.440 .960 & 17.526 .178 \\
\hline
\end{tabular}




\begin{tabular}{|c|l|c|c|c|c|c|}
\hline 8 & Kepahiang & 105 & - & 69.594 .630 & 1.585 .056 & 16.646 .124 \\
\hline 9 & $\begin{array}{l}\text { Bengkulu } \\
\text { Tengah }\end{array}$ & 142 & - & 94.118 .452 & 2.017 .344 & 17.855 .178 \\
\hline
\end{tabular}

Source : Transfer of Village Fund Accounts in 2020

From the table above, the highest number of villages is in North Bengkulu Regency as many as 215 villages and the least is Lebong Regency with 93 (figure 1). The graph of the number of villages in each district is shown in the following figure;

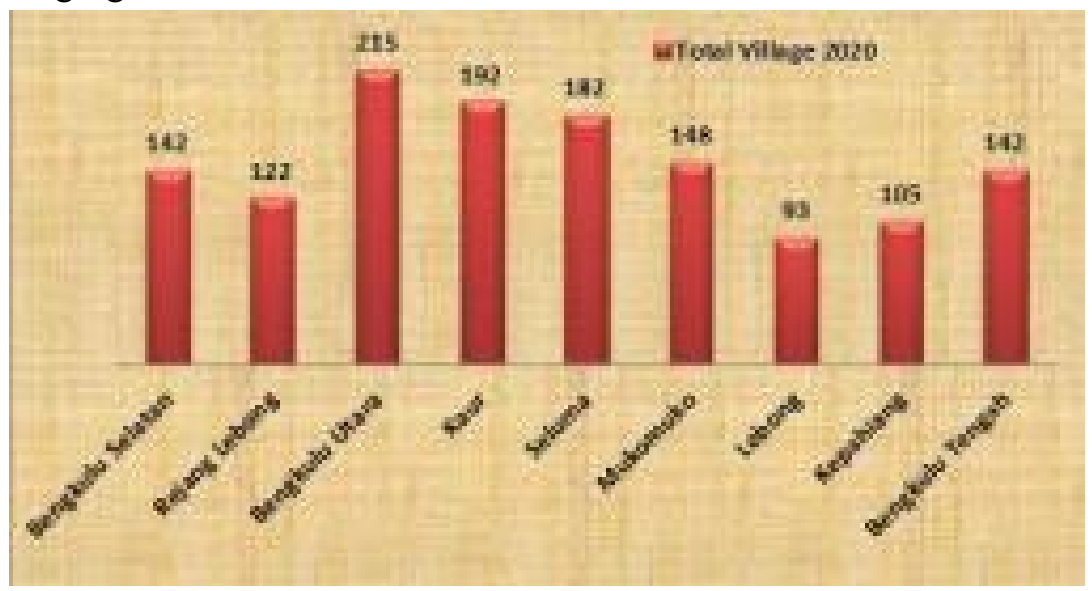

Fig 1. Total Villages in Each District in 2020

Confirmation Allocation is determined at 3\% (three percent) of the Village Fund spending plan isolated relatively to immature towns and exceptionally immature towns that have countless destitute individuals. Recipe Allocation is a designation determined by considering the quantity of Village occupants, Village destitution rate, Village region, and the degree of topographical trouble of the Village in each locale/city. Equation designation is determined at $25 \%(25 \%)$ of the Village Fund spending plan partitioned dependent on the quantity of Village inhabitants, the quantity of helpless Village occupants, the space of the Village, and the degree of geological trouble of the Village with loads. For Bengkulu Province, the Affirmation allotments are Seluma Regency and North Bengkulu Regency. The chart of the absolute allotment of certifications in each locale is displayed in the accompanying figure;

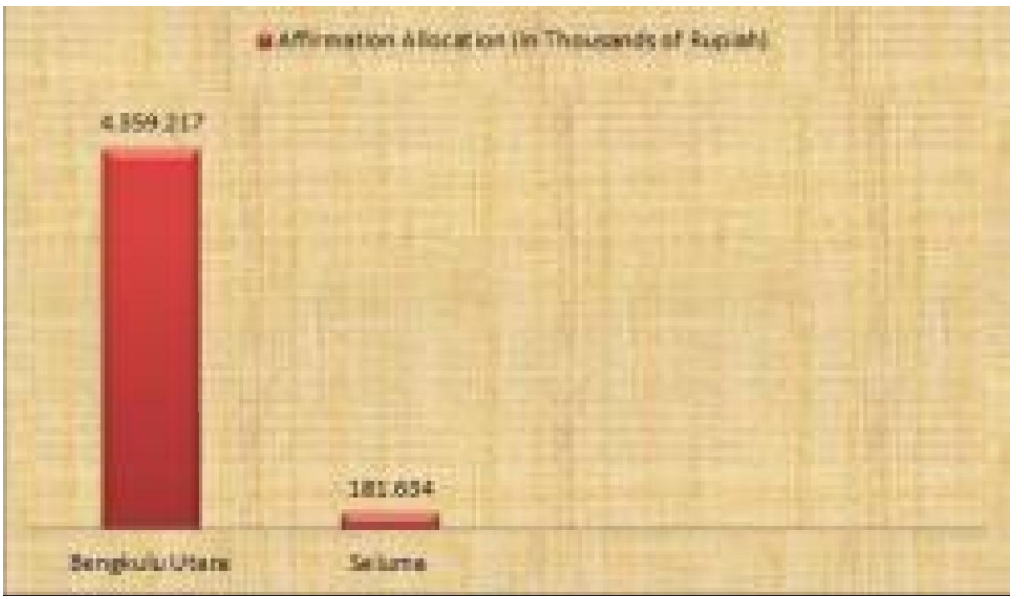

Fig 2. Total Village Funds in Affirmation Allocation for Fiscal Year 2020

Village funds allocated based on the basic allocation (figure 2) were mostly given to Rejang Lebong Regency at 142,503,290 (in thousands of rupiah) and the lowest basic allocation was to Lebong Regency at $61,640,958$ (in thousands). rupiah). The graph of the Total Basic Allocation given to each District is shown in the following figure; 


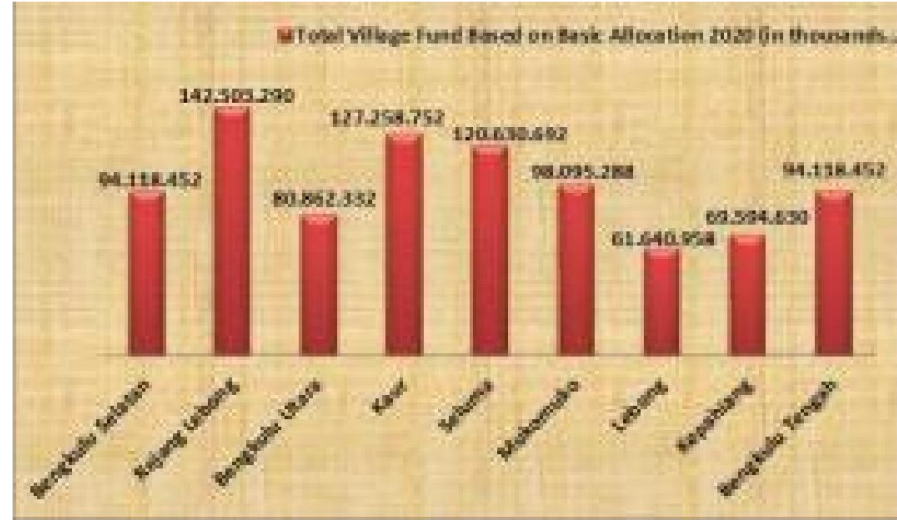

Fig 3. Total Village Funds in the Basic Allocation for Fiscal Year 2020

The highest Village Funds allocated based on Performance Allocation (figure 3) were given to Rejang Lebong Regency of 3,170,112 (in thousands of rupiah) and the lowest Performance Allocation for Lebong Regency of 1,440,960 (in thousands of rupiah). The graph of the Total Basic Allocation given to each District is shown in the following figure;

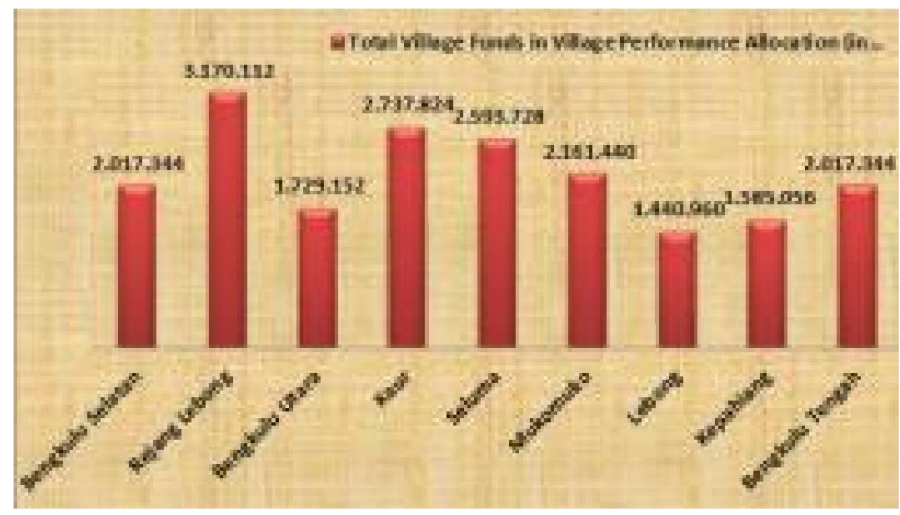

Fig 4. Total Village Funds in the 2020 Budget Village Performance Allocation

The most Village Funds allocated based on Formula Allocation (figure 4) were given to Rejang Lebong Regency of 27,577,562 and the lowest Formula Allocation was in Bengkulu Selatan Regency of 16,373,993 (in thousands of rupiah). (in thousands of rupiah). The graph of the Total Basic Allocation given to each District is shown in the following figure;

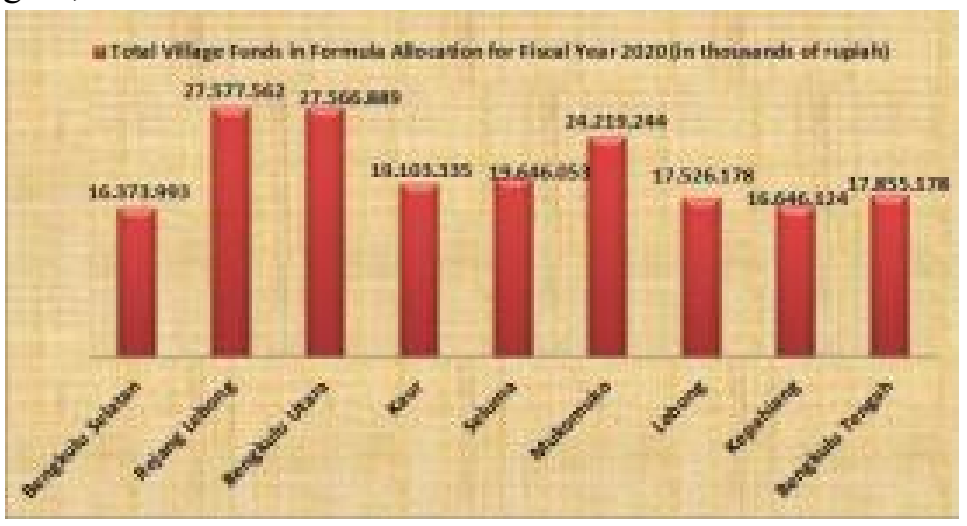

Fig 5. Total Village Funds in Formula Allocation for Fiscal Year 2020

\section{Relationship Between Village Fund Allocation and Number of Villages}

To find out the magnitude of the relationship between Village Fund Allocation (ADD) and Number of Villages, we used the IBM SPSS Statistics 22 tool. The following are the results obtained after we conducted the test the relationship between the Village Fund Allocation (ADD) to the Number of Villages; 
Tabel 2. Relationship Between Allocation Dana Village (ADD) to Total Village

\begin{tabular}{|c|c|c|c|}
\hline & & $\mathrm{ADD}$ & Total Village \\
\hline \multirow[t]{3}{*}{$\overline{\mathrm{ADD}}$} & $\begin{array}{l}\text { Pearson } \\
\text { Correlation }\end{array}$ & 1 & , 411 \\
\hline & Sig. (2-tailed) & & 272 \\
\hline & $\mathrm{N}$ & 9 & 9 \\
\hline \multirow[t]{3}{*}{ Jumlah Desa } & $\begin{array}{l}\text { Pearson } \\
\text { Correlation }\end{array}$ & ,411 & 1 \\
\hline & Sig. (2-tailed) &, 272 & \\
\hline & $\mathrm{N}$ & 9 & 9 \\
\hline
\end{tabular}

Source; 2021 Data Processing Results

Obtained From the results of the relationship between the village fund allocation to the 9th District in the Province of Begkulu on the number of villages all District Bengkulu province shows the relationship that Medium (0.41 s / d 0.60). The result of the relationship between the allocation of village funds to the number of villages in Bengkulu Province is $\mathbf{0 . 4 1 1}$.

\section{CONCLUSION}

The distribution of town finances given to every district is as per the Regulation of the Minister of Finance of the Republic of Indonesia No. 193/Pmk.07/2018, the Basic Allocation has been determined at 72\% (72\%) of the Village Fund spending plan isolated similarly among each town. The Formula Allocation given to every district is as per the Regulation of the Minister of Finance of the Republic of Indonesia No. 193/Pmk.07/2018 article 5 that the Formula Allocation is determined at 25\% (25\%) of the Village Fund financial plan separated by the quantity of Village inhabitants, the quantity of rustic destitute individuals, the space of the town, and the degree of topographical trouble. Notwithstanding, for Village Performance Assessment on Performance Allocations in the portion of Village Funds in 2020 and 2021, the Central Government is as yet doing, Completing strategies in the distribution of Village Funds to Villages, one of which is by giving Performance Allocations (AK) to towns that have the best presentation appraisal results.

The designation of town reserves depends on the Regulation of the Minister of Finance of the Republic of Indonesia No. 193/Pmk.07/2018, which incorporates Basic Allocations, Performance Allocations, Formulation Allocations, in light of the quantity of towns in every city/region in Bengkulu are as per the following;

1. The most villages are in North Bengkulu Regency, as many as 215 villages

2. The least villages are in Lebong Regency, as many as 122 Villages

3. The largest Basic Allocation is received by Rejang Lebong Regency, amounting to 142,503,290

4. The smallest Basic Allocation is received by Lebong Regency, amounting to 61,640,958

5. The performance allocation received by the Rejang Lebong, amounting to 3,170,112

6. Allocation of the smallest performance received by Lebong, amounting to 1.44096 million

7. The allocation formula is accepted by Rejang Lebong, amounting to $27,577,562$

8. The smallest formula allocation was accepted by South Bengkulu Regency, amounting to 16,373.993.moderate

Meanwhile, the correlation test results obtained the results that the relationship between the 9th district village fund allocation and the number of villages showed a relationship . For additional exploration, further investigation can be done, connected with the reasons for the feeble connection between the portion of the Village Fund Budget (ADD) to the quantity of towns in each region. The following analyst can add different factors, like the quantity of town occupants, the quantity of needy individuals and the degree of topographical trouble of the town. 


\section{ACKNOWLEDGMENTS}

We thank the exploration group for this coordinated effort. Much thanks to you to the college for allowing us to uncover in this exploration. This exploration can be helpful for us all, particularly for the public authority in deciding how much the Village Fund Budget (ADD).

\section{REFERENCES}

[1] Aslan, D. C. D., \& Wijaya, A. (2019). Have Village Funds Impact Growth Economy And Poverty Rate? In researchgate.net.

https://www.researchgate.net/profile/Dio_Caisar_Darma/publication/342492013_Have_Village_Funds_Impact_Gro wth_Economy_And_Poverty_Rate/links/5ef6f49c45851550507535d3/Have-Village-Funds-Impact-GrowthEconomy-And-Poverty-Rate.pdf

[2] Enceng, Ismiyarto, \& Wahyuni, P. M. (2020). Improving management performance of village development by encouraging the implementation of village fund policy. Test Engineering and Management, 83(482), 482-492.

[3] Fadli, M. N., Aulia, T. B., \& Rani, H. A. (2020). Cost management in allocating village funds for infrastructure development. International Journal of Psychosocial Rehabilitation, 24(Special Issue 2), 486-495. https://doi.org/10.37200/IJPR/V24SP2/PR201338

[4] Florensi, H. (2014). Pelaksanaan Kebijakan Alokasi Dana Desa ( ADD ) dalam Memberdayakan Masyarakat Desa di Desa Cerme, Kecamatan Grogol, Kabupaten Kediri. Kebijakan Dan Manajemen Publik, 2(1), 1-8.

[5] Irma, A. (2015). Akuntabilitas Pengelolaan Alokasi Dana Desa (ADD) di Kecamatan Dolo Selatan Kabupaten Sigi, e-Jurnal Katalogis. E-Jurnal Katalogis, 3(1), 121-137.

[6] Menkhoff, L., \& Rungruxsirivorn, O. (2011). Do village funds improve access to finance? Evidence from Thailand. World Development, 39(1), 110-122. https://doi.org/10.1016/j.worlddev.2010.09.002

[7] Mujtahid, I. M., \& Darmi, T. (2019). Reinforcement the capacity of village fund management to improve the economy of local communities (Indonesia example). International Journal of Scientific and Technology Research, $8(10), 3659-3668$.

https://www.scopus.com/inward/record.uri?partnerID=HzOxMe3b\&scp=85074503958\&origin=inward

[8] Pendampingan, M. (2021). Pedoman Penilaian Kinerja Desa dalam Penentuan Alokasi Kinerja Dana Desa Tahun 2022. Pendampingdesa.Com.

[9] Ramly, A. R., Wahyuddin, W., Mursyida, J., \& Mawardati, M. (2018). The Implementation of Village Fund Policy in Improving Economy of Village Society. Jurnal Ilmiah Peuradeun, 6(3), 459. https://doi.org/10.26811/peuradeun.v6i3.184

[10] Sukmawati, F., \& Saudi, M. H. M. (2019). Effects of utilization of village funds on community empowerment in Indonesia. International Journal of Innovation, Creativity and Change, 6(5), 15-23. https://www.scopus.com/inward/record.uri?partnerID=HzOxMe3b\&scp=85072995019\&origin=inward

[11] Surya Adi Tama, P., \& Wirama, D. G. (2020). Akuntabilitas Pemerintah Desa dalam Pengelolaan Alokasi Dana Desa. E-Jurnal Akuntansi, 30(1), 73. https://doi.org/10.24843/eja.2020.v30.i01.p06

[12] Susanti, M., Karim, K., Rimbano, D., \& Yustanti, N. V. (2020). Realization of Village Income and Expenditure Budget ( APBDes ); Case Study in Seluma District, Bengkulu Province. The International Conference on Innovations in Social Sciences and Education,

412-425. http://conference.loupiasconference.org/index.php/ICoISSE/issue/view/3

[13] Watts, J. D., Tacconi, L., Irawan, S., \& Wijaya, A. H. (2019). Village transfers for the environment: Lessons from community-based development programs and the village fund. Forest Policy and Economics, 108(July). https://doi.org/10.1016/j.forpol.2019.01.008 